\title{
THE RESPONSE OF Adenanthera pavonina L. AND Parkinsonia aculeata L. TO HOUSEHOLD DETERGENT SOLUTION
}

\author{
AAMNA RIZVI*, MUHAMMAD ZAFAR IQBAL, SEHRISH KHURSHEED \\ Department of Botany, University of Karachi, Karachi-75270, Pakistan; e-mail: amna_javeed@hotmail.com \\ ${ }^{*}$ Author for correspondence
}

\begin{abstract}
Rizvi A., Iqbal M.Z., Khursheed S.: The response of Adenanthera pavonina L. and Parkinsonia aculeata L. to household detergent solution. Ekológia (Bratislava), Vol. 33, No. 2, p. 171-177, 2014.

The growth of Adenanthera pavonina L. and Parkinsonia aculeata L. was studied in soil irrigated with household detergent solution of different concentrations $(0,0.25$ and $0.5 \%)$ under natural environmental conditions. Detergent solutions exhibited great inhibition of all the observed growth parameter of Adenanthera pavonina and Parkinsonia aculeata. Growth of plants extremely declined when irrigated with 0.75 and $1 \%$ treatments and died after two weeks of experiment. Analysis of soil showed that detergent solution has resulted in significant increase of $\mathrm{pH}$, soluble sodium and chlorides. Soluble potassium and total phosphate were significantly decreased in soil irrigated with detergent solutions as compared to control.
\end{abstract}

Key words: detergent, plant, growth, stress, salinity.

\section{Introduction}

Detergents are household chemicals widely used for laundering and dishwashing. Even though detergents do a tremendous job of getting rid of the dirt and grime in our fabrics but considering the toxicities of the chemical ingredients and carbon cost of production, it is a matter of concern about the impact of laundry detergents on the environment and plants. Laundry detergent typically consists of surfactants, which act as the washing agent to remove the dirt from the clothes, and phosphorus, which make clothes appear whiter. Many kinds of molecules and ions can serve as high-efficiency surfactants (Smulders et al., 2002).

Detergents are often classified according to the charge of the molecule or ion; three main classes are anionic, neutral and cationic detergents. Anionic detergents are most commonly encountered in our daily lives as domestic laundry detergents (Smulders et al., 2002). Usage of detergent or recycled laundry water in garden can permanently damage the soil and make it infertile for future growth of plants. Detergents can also disrupt the natural percolation of soil. It is suggested that surfactant accumulation in soil due to grey water irrigation can create water repellent soils (Wiel-Shafran et al., 2006). The exposure of roots of plants to the surfactant solution causes ions and amino acid leakage from roots, presumably due to loss of membrane integrity. Toxic ef- 
fects varied with surfactant and its concentration (Horowitz, Givelberg, 1979). Surfactant in high concentrations caused stronger damages at cytological levels (Bruschi et al., 1998).

The most common sources of salts are sodium, calcium, magnesium, chloride and sulphate ions, sodium-based soaps, nitrates and phosphates found in detergents and powdered soaps (Morel, Diener, 2006). Salt stress brought about a reduction of the growth and protein content (Hameed et al., 2008). There is a decrease in water uptake and germination of all studied cultivars of Triticum aestivum $\mathrm{L}$. under salt stress. Increased salt concentration also affected the early seedling growth (Rahman et al., 2008).

According to the EPA (1999), the major concerns about the chemical ingredients used in laundry detergents are: they cause toxicity to aquatic organisms and algae, persistence in the environment and eutrophication of fresh water, particularly by phosphate-based detergents, and health problems in people, such as cancer. Cserhati et al. (2002) found that they cause serious environmental pollution with toxic effects on living organism.

For study purpose Adenanthera pavonina L. and Parkinsonia aculeata L. were selected. Adenanthera pavonina (family Mimosaceae) is a secondary forest tree favouring precipitation. Adenanthera species are found scattered in primary and secondary, evergreen to dry deciduous rainforests, but also in open savannah. It is found on a variety of soils from deep, well drained to shallow and rocky, this tree prefers neutral to slightly acidic soils (Adkins, 1994). Parkinsonia aculeata (family Caesalpiniaceae) is a species of perennial flowering tree. It has a high tolerance to drought, but in difficult habitat it grows as a shrub. In moist and humus rich environments, it becomes a small tree. This plant prefers a full sun exposure, but can grow on a wide range of soils at an altitude of $0-300 \mathrm{~m}(0-980 \mathrm{ft}$.) above sea level.

The main object of this study is to find the response of Adenanthera pavonina and Parkinsonia aculeata growth to household detergent solution.

\section{Material and methods}

A branded washing powder at the concentration of $0,0.25,0.5,0.75$ and $1 \%$ was used as sample detergent for the experimental purpose. Healthy and uniform size seeds of Adenanthera pavonina L. were collected from Karachi University campus and Parkinsonia aculeata L. were collected from Safari Park. Because of hard seed coat, seeds were placed in distilled water for $24 \mathrm{~h}$ and then sown in large earthen pot containing $5 \mathrm{~kg}$ of garden soil. The fraction of garden soil was one part manure and two parts fine sand. After 4 weeks of germination, one seedling was transplanted in a plastic pot of $7.3 \mathrm{~cm}$ in diameter and $9.6 \mathrm{~cm}$ in depth, containing garden soil and was irrigated with detergent solutions of different concentrations $(0.25,0.5,0.75$ and $1 \%)$ on alternate days. Each treatment was replicatedlicated five times and pots were arranged in randomized complete block design. Experiment was conducted in natural environment for 6 weeks. Pots were reshuffled accordingly to avoid any shade and light effect.

All the seedlings of Adenanthera pavonina and Parkinsonia aculeata were carefully removed from the pots after 6 weeks. Plants were thoroughly washed to measure root, shoot and seedling length. Root, shoot and leaves were separated for drying in an oven at $80^{\circ} \mathrm{C}$ for $24 \mathrm{~h}$. Root, shoot and total plant weight of oven-dried samples were measured by electrical balance. Root/shoot ratio, leaf weight ratio, specific leaf area and leaf area ratio were determined by the formula given by Rehman and Iqbal (2009). Reduction in percentage of all the growth parameters was determined using the formula given by Rehman and Iqbal (2007).

To carry out soil analysis, control as well as detergent-treated soil was first dried in an oven at $80^{\circ} \mathrm{C}$ for $24 \mathrm{~h}$ and then passed through a 2-mm sieve for physical and chemical analysis. Soil $\mathrm{pH}$ was recorded by a direct $\mathrm{pH}$-reading meter $(\mathrm{AD}$ $1000 \mathrm{pH}$ meter). Electrical conductivity (EC) was determined by EC meter (AGB 1000). Maximum water holding capacity (MWHC) was measured by the method of Keen (1931). Bulk density and total porosity was determined by using the core method described by Birkeland (1984). Soluble sodium and potassium were determined by the method of Moore 
and Chapman (1986), using flame photometer. Chlorides were evaluated through titration by Mohr's method (Allen et al., 1974). Total phosphates were determined by the method of Oslen and Sommer (1982).

Statistical analysis was performed by analysis of variance (ANOVA) and Duncan's multiple range test (DMRT) (Duncan, 1955; $p<0.05$ ) using personal computer software packages SPSS version 13.0.

\section{Results}

Irrigation of Adenanthera pavonina with detergent solution pronouncedly reduced all growth variables (Tables 1 and 2). Root length $(1.86 \mathrm{~cm})$, shoot length $(3.64 \mathrm{~cm})$, seedling length $(5.5 \mathrm{~cm})$, circumference $(1.5 \mathrm{~cm})$, root dry weight $(0.01 \mathrm{~g})$, shoot dry weight $(0.02 \mathrm{~g})$, total plant dry weight $(0.03 \mathrm{~g})$ and root/shoot ratio (0.5) of A. pavonina were decreased significantly in $0.25 \%$ detergent solution irrigated soil. Similarly in $0.5 \%$ detergent treatment, root length $(2.44 \mathrm{~cm})$, shoot length $(3.58 \mathrm{~cm})$, seedling length $(5.3 \mathrm{~cm})$, circumference $(1.5 \mathrm{~cm})$, root dry weight $(0.01 \mathrm{~g})$, shoot dry weight $(0.01 \mathrm{~g})$, total plant dry weight $(0.02 \mathrm{~g})$ and root/shoot ratio (1), were greatly reduced as compared to root length $(5.38 \mathrm{~cm})$, shoot length $(6.17 \mathrm{~cm})$, seedling length $(11.5 \mathrm{~cm})$, circumference $(34.33 \mathrm{~cm})$, root dry weight $(0.07 \mathrm{~g})$, shoot dry weight $(0.06 \mathrm{~g})$, total plant dry weight $(0.19 \mathrm{~g})$ and root/shoot ratio (1.17) of control soil (Tables 1 and 2). When A. pavonina was irrigated with 0.75 and $1 \%$ detergent solution, the seedling did not survive after 2 weeks.

$\mathrm{T}$ a b l e 1. Effects of detergent solutions on growth of Adenanthera pavonina.

\begin{tabular}{|c|c|c|c|}
\hline Treatments & 0\% & $0.25 \%$ & $0.5 \%$ \\
\hline Root length $(\mathrm{cm})$ & $5.38 \mathrm{~b} \pm 0.41$ & $1.86 \mathrm{a} \pm 0.01$ & $2.44 \mathrm{a} \pm 0.02$ \\
\hline Shoot length $(\mathrm{cm})$ & $6.17 b \pm 0.03$ & $3.64 \mathrm{a} \pm 0.03$ & $3.58 \mathrm{a} \pm 0.03$ \\
\hline Seedling length $(\mathrm{cm})$ & $11.5 \mathrm{~b} \pm 0.44$ & $5.5 \mathrm{a} \pm 0.02$ & $5.3 \mathrm{a} \pm 0.5$ \\
\hline Circumference $(\mathrm{cm})$ & $34.33 \mathrm{~b} \pm 1.33$ & $1.5 \mathrm{a} \pm 0$ & $1.5 \mathrm{a} \pm 0$ \\
\hline Root dry weight (g) & $0.07 \mathrm{~b} \pm 0.01$ & $0.01 \mathrm{a} \pm 0.01$ & $0.01 \mathrm{a} \pm 0.01$ \\
\hline Shoot dry weight (g) & $0.06 \mathrm{~b} \pm 0.07$ & $0.02 \mathrm{a} \pm 0.01$ & $0.01 \mathrm{a} \pm 0.01$ \\
\hline Total plant dry weight (g) & $0.19 \mathrm{~b} \pm 0.01$ & $0.03 \mathrm{a} \pm 0.01$ & $0.02 \mathrm{a} \pm 0.01$ \\
\hline Root/shoot ratio & $1.17 \mathrm{~b} \pm 0.06$ & $0.5 \mathrm{a} \pm 0.01$ & $1 \mathrm{~b} \pm 0.5$ \\
\hline
\end{tabular}

Statistical significance determined by analysis of variance. According to DMRT, number followed by the same alphabet letters in the same row is not significantly different at $\mathrm{p}<0.05$. \pm Standard error.

T a ble 2. Percentage reduction in growth of Adenanthera pavonina treated with detergent solutions.

\begin{tabular}{|l|c|c|}
\hline Treatments & $\mathbf{0 . 2 5 \%}$ & $\mathbf{0 . 5 \%}$ \\
\hline Root length & 65.42 & 54.64 \\
\hline Shoot length & 41 & 41.97 \\
\hline Seedling length & 52.17 & 53.91 \\
\hline Circumference & 95.63 & 95.63 \\
\hline Root dry weight & 85.71 & 85.71 \\
\hline Shoot dry weight & 66.67 & 83.33 \\
\hline Total plant dry weight & 84.21 & 89.47 \\
\hline Root/shoot ratio & 57.26 & 14.53 \\
\hline
\end{tabular}

Parkinsonia aculeata showed notable reduction $(p<0.05)$ in leaf area $\left(0.17 \mathrm{~cm}^{2}\right)$, root dry weight $(0.01 \mathrm{~g})$, shoot dry weight $(0.04 \mathrm{~g})$, leaf dry weight $(0.026 \mathrm{~g})$, total plant dry weight $(0.076 \mathrm{~g})$ and leaf weight ratio $(0.34)$ under $0.25 \%$ treatment. At $0.5 \%$ treatment leaf area 
$\left(0.16 \mathrm{~cm}^{2}\right)$, root dry weight $(0.006 \mathrm{~g})$, shoot dry weight $(0.02 \mathrm{~g})$, leaf dry weight $(0.008 \mathrm{~g})$, total plant dry weight $(0.034 \mathrm{~g})$ and leaf weight ratio $(0.24)$ were distinctly decreased as compared with leaf area $\left(0.38 \mathrm{~cm}^{2}\right)$, root dry weight $(0.03 \mathrm{~g})$, shoot dry weight $(0.1 \mathrm{~g})$, leaf dry weight $(0.076 \mathrm{~g})$, total plant dry weight $(0.206 \mathrm{~g})$ and leaf weight ratio $(0.37)$ (Table 3$)$.

Shoot length (53.73\%), seedling length (48.64\%), number of leaves $(69 \%)$ and circumference $(53.38 \%)$ of $P$. aculeata was markedly reduced by $0.5 \%$ detergent solution irrigation while insignificant decline in shoot length, seedling length, number of leaves and circumference was observed in $0.25 \%$ detergent treatment (Table 4). Irrigation of $P$. aculeata with 0.75 and $1 \%$ detergent solution caused death after 2 weeks.

T a b l e 3. Effects of detergent solutions on growth of Parkinsonia aculeata.

\begin{tabular}{|c|c|c|c|}
\hline Treatments & 0\% & $0.25 \%$ & $0.5 \%$ \\
\hline Root length $(\mathrm{cm})$ & $5.15 \mathrm{a} \pm 0.18$ & $5 \mathrm{a} \pm 0.07$ & $4.49 \mathrm{a} \pm 1.23$ \\
\hline Shoot length $(\mathrm{cm})$ & $9.9 \mathrm{~b} \pm 0.4$ & $9.52 \mathrm{~b} \pm 0.19$ & $4.58 \mathrm{a} \pm 1.87$ \\
\hline Seedling length $(\mathrm{cm})$ & $14.8 \mathrm{~b} \pm 0.42$ & $14.5 \mathrm{~b} \pm 0.18$ & $7.6 \mathrm{a} \pm 3.11$ \\
\hline No. of leaves & $10.4 \mathrm{~b} \pm 2.44$ & $6.8 \mathrm{~b} \pm 8.6$ & $3.2 \mathrm{a} \pm 17.99$ \\
\hline Leaf area $\left(\mathrm{cm}^{2}\right)$ & $0.38 \mathrm{~b} \pm 0.01$ & $0.17 \mathrm{a} \pm 0.004$ & $0.16 \mathrm{a} \pm 0.3$ \\
\hline Circumference $(\mathrm{cm})$ & $26 \mathrm{~b} \pm 0.16$ & $20 \mathrm{~b} \pm 1.64$ & $12 \mathrm{a} \pm 5.14$ \\
\hline Root dry weight (g) & $0.03 \mathrm{~b} \pm 0.01$ & $0.01 \mathrm{a} \pm 0.004$ & $0.006 \mathrm{a} \pm 0.002$ \\
\hline Shoot dry weight (g) & $0.1 \mathrm{~b} \pm 0.01$ & $0.04 \mathrm{a} \pm 0.01$ & $0.02 \mathrm{a} \pm 0.01$ \\
\hline Leaf dry weight (g) & $0.076 \mathrm{~b} \pm 0.01$ & $0.026 \mathrm{a} \pm 0.01$ & $0.008 \mathrm{a} \pm 0.003$ \\
\hline Total plant dry weight (g) & $0.206 \mathrm{~b} \pm 0.02$ & $0.076 \mathrm{a} \pm 0.01$ & $0.034 \mathrm{a} \pm 0$ \\
\hline Root/shoot ratio & $0.31 \mathrm{a} \pm 0.04$ & $0.25 \mathrm{a} \pm 0.12$ & $0.3 \mathrm{a} \pm 0.09$ \\
\hline Leaf weight ratio & $0.37 \mathrm{~b} \pm 0.02$ & $0.34 \mathrm{a} \pm 0.05$ & $0.24 \mathrm{a} \pm 0.07$ \\
\hline Specific leaf area $\left(\mathrm{cm}^{2} \mathrm{~g}^{-} 1\right)$ & $5 \mathrm{a} \pm 0.49$ & $6.53 \mathrm{a} \pm 2.88$ & $20 \mathrm{a} \pm 11.2$ \\
\hline Leaf area ratio $\left(\mathrm{cm}^{2} \mathrm{~g}^{-1}\right)$ & $1.85 \mathrm{a} \pm 0.18$ & $2.24 \mathrm{a} \pm 0.15$ & $4.17 \mathrm{a} \pm 10.25$ \\
\hline
\end{tabular}

According to DMRT, number followed by the same alphabet letters in the same row is not significantly different at $\mathrm{p}<0.05 . \pm$ Standard error.

T a b l e 4. Percentage reduction in growth of Parkinsonia aculeata treated with detergent solutions.

\begin{tabular}{|l|c|c|}
\hline Treatments & $\mathbf{0 . 2 5 \%}$ & $\mathbf{0 . 5 \%}$ \\
\hline Root length & 2.91 & 12.82 \\
\hline Shoot length & 38.38 & 53.73 \\
\hline Seedling length & 2.02 & 48.64 \\
\hline No. of leaves & 34.6 & 69 \\
\hline Leaf area & 55.26 & 57.89 \\
\hline Circumference & 23.07 & 53.38 \\
\hline Root dry weight & 66.67 & 80 \\
\hline Shoot dry weight & 60 & 80 \\
\hline Leaf dry weight & 65.78 & 89.47 \\
\hline Total plant dry weight & 63.11 & 83.5 \\
\hline Root/shoot ratio & 19.36 & 3.23 \\
\hline Leaf weight ratio & 8.11 & 35.14 \\
\hline Specific leaf area & +30.6 & +300 \\
\hline Leaf area ratio & +21.08 & +125.41 \\
\hline
\end{tabular}

+ Denotes percentage increase. 
Soil analysis showed that application of detergent solution resulted in significant increase in $\mathrm{pH}$ at $0.5 \%(8.06)$ as compared to control (7.93) (Table 5). Soluble sodium increased at $0.25 \%(430 \mathrm{ppm})$ and $0.5 \%(700 \mathrm{ppm})$ as compared to control (140 ppm). Significant elevated level of chlorides was also observed at $0.5 \%\left(13.14 \mathrm{meqL}^{-1}\right)$ as compared to control (4.82 meq $\left.\mathrm{L}^{-1}\right)$. Whereas, soluble potassium significantly decreased when treated with $0.25 \%$ (95 ppm) and $0.5 \%(85 \mathrm{ppm})$ as compared to control $(140 \mathrm{ppm})$ and total phosphate was also significantly decreased in soil irrigated with detergent solutions: $0.25 \%\left(1.033 \mathrm{mg} \mathrm{g}^{-1}\right)$ and $0.5 \%$ (1.020 $\left.\mathrm{mg} \mathrm{g}^{-1}\right)$ as compared to control $\left(1.185 \mathrm{mg} \mathrm{g}^{-1}\right)$. No significant changes in bulk density, porosity, MWHC and EC were observed.

T a b l e 5. Physical and chemical analysis of detergent-treated soil.

\begin{tabular}{|l|c|c|c|}
\hline Treatments & $\mathbf{0 \%}$ & $\mathbf{0 . 2 5 \%}$ & $\mathbf{0 . 5 \%}$ \\
\hline Bulk density $\left(\mathrm{g} \mathrm{cm}^{-3}\right)$ & $1.55 \mathrm{a} \pm 0.02$ & $1.54 \mathrm{a} \pm 0.025$ & $1.52 \mathrm{a} \pm 0.01$ \\
\hline Porosity $(\%)$ & $41.69 \mathrm{a} \pm 0.95$ & $41.88 \mathrm{a} \pm 0.01$ & $43.01 \mathrm{a} \pm 0.01$ \\
\hline $\mathrm{MWHC}(\%)$ & $42.63 \mathrm{a} \pm 0.45$ & $40.83 \mathrm{a} \pm 0.45$ & $40.91 \mathrm{a} \pm 0.43$ \\
\hline $\left.\mathrm{EC}(\mathrm{mS} \mathrm{cm})^{-1}\right)$ & $0.6 \mathrm{a} \pm 0.05$ & $0.55 \mathrm{a} \pm 0.05$ & $0.6 \mathrm{a} \pm 0.02$ \\
\hline $\mathrm{pH}$ & $7.93 \mathrm{a} \pm 0.04$ & $7.88 \mathrm{a} \pm 0.01$ & $8.06 \mathrm{~b} \pm 0.01$ \\
\hline Soluble K+ $(\mathrm{ppm})$ & $140 \mathrm{c} \pm 0.5$ & $95 \mathrm{~b} \pm 5.0$ & $85 \mathrm{~b} \pm 5.0$ \\
\hline Soluble Na+ $(\mathrm{ppm})$ & $140 \mathrm{a} \pm 2.56$ & $430 \mathrm{~b} \pm 5.75$ & $700 \mathrm{c} \pm 10$ \\
\hline $\mathrm{Cl}^{-}\left(\mathrm{meq} \mathrm{L}^{-1}\right)$ & $4.82 \mathrm{a} \pm 0.13$ & $4.65 \mathrm{a} \pm 0.13$ & $13.14 \mathrm{~b} \pm 0.3$ \\
\hline Total phosphates $\left(\mathrm{mg} \mathrm{g}^{-1}\right)$ & $1.185 \mathrm{~b} \pm 1.05$ & $1.033 \mathrm{a} \pm 4.55$ & $1.020 \mathrm{a} \pm 1.8$ \\
\hline
\end{tabular}

MWHC, maximum water holding capacity; $\mathrm{EC}$, electrical conductivity; $\mathrm{K}^{+}$, potassium; $\mathrm{Na}^{+}$, sodium; $\mathrm{Cl}^{-}$, chlorides. Statistical significance determined by analysis of variance. According to DMRT, number followed by the same alphabet letters in the same row is not significantly different at $\mathrm{p}<0.05$. \pm Standard error.

\section{Discussion}

Growth of Adenanthera pavonina and Parkinsonia. aculeata plants irrigated with detergent solution was lower than the plants irrigated with normal water, indicating that constituents of detergent solution were detrimental to plants. Root, shoot and seedling length of Adenanthera pavonina showed reduction at 0.25 and $0.5 \%$ treatments whereas shoot and seedling length of Parkinsonia aculeata reduced at $0.5 \%$ treatment. The $\mathrm{pH}$ of soil after detergent solution treatment was in the range of 7.88-8.06. Therefore, the most likely reason for reduction in growth may be the high $\mathrm{pH}$ of detergent irrigated soil. Because at high $\mathrm{pH}$, availability of many essential elements present in soil become restricted (Marschner, 1995), making soil nutrient deficient that ultimately leads to the decrease in plant growth. The high alkali stress might be one of the reasons for decrease in phosphorus and potassium concentration in soil.

The circumference, root, shoot and total plant dry weight and root/shoot ratio was greatly decreased. This may be due to the elevated sodium and chloride concentrations in detergent, that are included as main washing agent in detergents and powdered soaps along with phosphates and nitrates (Morel, Diener, 2006). This indicates that detergent solution has created the problem of soil salinisation. Summart (2010) has came up with the same results that growth and crop productivity greatly reduced due to the inhibitory effect of salt stress in plants. The higher levels of salts in soil has affected plant growth by reducing the ability of soil 
to absorb and retain water, increase soil osmotic potential, decrease in plant water uptake, and reduce availability of vital mineral nutrients needed for plant growth (Unkovich et al., 2004). Low concentration of phosphorus in soil could also be due to the salt stress. In results, it is evaluated that sodium content increased and the potassium content decreased due to salinity, indicating competitive inhibition between the absorption of sodium and potassium.

According to Strogonov (1964), soluble salts in the soil reduce the osmotic potential, which brought a state of 'physiological drought', particularly for plants that cannot adjust their osmotic potential. Death of Adenanthera pavonina and Parkinsonia. aculeata in 0.75 and $1 \%$ detergent treatments might be because of the physiological drought. Specific leaf area and leaf area ratio of $P$. aculeate strikingly increased at 0.25 and $0.5 \%$ treatments. The rise in these parameters is probably due to the homeostatic adjustment of plant under stressed conditions. According to Rao et al. (2001), in such stress status the leaf of plant may function as a temporary storage pool even though there is reduction in photosynthetic capacity and produce favourable charbohydrates (Dale, Causton, 1992), hence results in elevation of specific leaf area and leaf area ratio.

\section{Conclusion}

This study demonstrated that detergent solutions adversely affected the growth of Adenanthera pavonina and Parkinsonia aculeata as well as soil characteristics. Plants that survived in detergent-treated soil showed stunted growth due to raised levels of sodium and chlorides. $P$. aculeata were comparatively more tolerant than Adenanthera pavonina.

\section{References}

Adkins, R.V.C. (1994). The role of agroforestry in the sustainability of South Pacific Islands: Species Trials in American Samoa. M.S. Thesis, Utah State University, Logan, Utah.

Allen, S.E., Grimshaw, M.H., Parkinson, J.A. \& Quarmby C. (1974). Chemical analysis of ecological materials. Oxford: Blackwell Scientific.

Birkeland, P.W. (1984). Bulk density determination. Soil and geomorphology. New York: Oxford University Press.

Bruschi, S.P., Bennici, A. \& Mori B. (1998). An example of in vitro test to study the effects of surfactants in plant material. Chemosphere, 36(4-5), 715-720. DOI: 10.1016/S0045-6535(97)10113-8.

Cserháti, T., Forgács, E. \& Oros Gy. (2002). Biological activity and environmental impact anionic surfactants. Environ. Int., 28(5), 337-348. DOI: 10.1016/S0160-4120(02)00032-6.

Dale, M.P. \& Causton D.R. (1992). The ecophysiology of Veronica chamaedrys, Veronica montana and Veronica officinalis II. The interaction of irradiance and water regime. J. Ecol., 80, 493-504. DOI: 10.2307/2260693.

Duncan, D.B. (1955). Multiple range and Multiple F-Test. Biometrics, 11, 1-42.

EPA (United states Environmental Protection Agency) (1999). "Key Characteristics of Laundry Detergent Ingredients." http://www.epa.gov/dfe/pubs/laundry/techfact/keychar.htm.

Hameed, A., Naseer, S., Iqbal, T., Syed, H. \& Haq M.A. (2008). Effects of $\mathrm{NaCl}$ salinity on seedling growth, senescence, catalase and protease activities in two wheat genotypes differing in salt tolerance. Pak. J. Bot., 40(3), 1043-1051.

Horowitz, M. \& Givelgerg A. (1979). Toxic effects of surfactants applied to plant roots. Pestic. Sci., 10(6), 547-557.

Keen, B.A. (1931). The physical properties of soil. New York: Longman Green and Company.

Marschner, H. (1995). Mineral nutrition of higher plants. New York: Academic Press.

Moore, P.D. \& Chapman S.B. (1986). Methods in plant ecology. Oxford: Blackwell.

Morel, A. \& Diener S. (2006). Greywater management in low and middle income countries, review of different treatment systems for households or neighbourhoods. Dübendorf: Swiss Federal Institute for Aquatic Science and Technology. 
Oslen, S.R. \& Sommer L.E. (1982). Methods of soil analysis and microbial properties. WI: Am. Soc. Madison.

Rahman, M., Soomro, U.A., Haq, M.Z. \& Gul S. (2008). Effects of $\mathrm{NaCl}$ salinity on wheat (Triticum aestivum L.) cultivars. World Journal of Agricultural Sciences, 4 (3), 398-403.

Rao, R.C.N., Talwar, H.S. \& Wright G.C. (2001). Rapid assessment of specific leaf area and leaf nitrogen in peanut (Arachis hypogaea L.) using a chlorophyll meter. J. Agron. Crop Sci., 186, 175-182. DOI: 10.1046/j.1439037X.2001.00472.X.

Rehman, S.A. \& Iqbal M.Z. (2007). Growth of Leucaena leucocephala (Lam.) de-Wit, in different soils of Korangi and Landhi industrial areas of Karachi, Pakistan. Pak. J. Bot., 39(5), 1701-1715.

Rehman, S.A. \& Iqbal M.Z. (2009). Growth of Leucaena leucocephala (Lam.) de-Wit in different soil compositions of Korangi and Landhi industrial areas of Karachi, Pakistan. Pak. J. Bot., 41(6), 3125-3138.

Smulders, E., Rybinski, W., Sung, E., Rähse, W., Steber, J., Wiebel, F. \& Nordskog A. (2002). "Laundry Detergents" in Ullmann's Encyclopedia of Industrial Chemistry. Weinheim: Wiley-VCH.

Strogonov, B.P. (1964). Physiological basis of salt tolerance of plants. Jerusalem: Israel Program for Scientific Translations.

Summart, J., Thanonkeo, P., Panichajakul, S., Prathepha, P. \& McManus M.T. (2010). Effects of salt stress on growth, inorganic ions, proline accumulation in Thai aromatic rice, Khao Dawk Mali 105, callus culture. African Journal of Biotechnology, 9(2), 145-152. http://www.academicjournals.org/AJB

Unkovich, M., Stevens, D., Ying, G. \& Kelly J. (2004). Impacts on crop quality from irrigation with water reclaimed from sewage. Australian Water Conservation and Reuse Research Program.

Wiel-Shafran, A., Ronen, Z., Weisbrod, N., Adar, E. \& Gross A. (2006). Potential changes in soil properties following irrigation with surfactant rich grey water. Ecological Engineering, 26, 348-354. DOI: 10.1016/j.ecoleng.2005.12.008. 